\title{
AJRC
}

\author{
Australia - Japan Research Centre
}

\section{A Comparison of the Wage Structure between the Public and Private Sectors in Japan*}

\section{AJRC Working Paper 07/2014 November 2014}

\section{Masayuki Morikawa}

The Research Institute of Economy, Trade and Industry (RIETI)

\section{Abstract}

This paper compares the wage structure between the public and private sectors in Japan by using a large microdata set covering public and private sector employees. Rather than comparing overall wage levels, we examine the differences in relative wages by gender, age, education, and region. According to the estimation of wage functions, wage gaps by gender and educational attainment are smaller in the public sector than in private companies. The public sector's age-wage profile is steeper than that of the private sector. Public sector wages are more compressed; the wages are relatively higher at the lower end of the wage distribution and relatively lower at the higher end. The regional wage differential is smaller in the public sector. As a result, the wage level of public sector workers is relatively higher in rural regions and relatively lower in large metropolitan regions. To ensure the efficient provision of public services, it is inappropriate to compare only average wages. We should carefully observe the differences in wage structure by individual characteristics and by region. 
* I am grateful to the Ministry of Internal Affairs and Communications and the Cabinet Office for providing the microdata of the Employment Status Survey used in this study. I would like to thank Masahisa Fujita, Arata Ito, Minoru Kaneko, Atsushi Nakajima, Futoshi Nasuno, Keiichiro Oda, Munehisa Yamashiro, and the seminar participants at RIETI for their helpful comments and suggestions. Any errors are my own.

\section{Keywords}

Public sector; Wage gap; Age-wage profile; Regional wage differential

\section{JEL Classification}

J31; J45; R23

\section{Suggested Citation}

Morikawa, M., 2014. A Comparison of the Wage Structure between the Public and Private Sectors in Japan, AJRC Working Paper No.7/2014, November. Australia-Japan Research Centre, Crawford School of Public Policy, The Australian National University.

This paper is also available at the RIETI website.

\section{Address for correspondence}

(E) ajrc@anu.edu.au

ISSN 07288409

ISBN 978-0-86413-011-2

The Australia-Japan Research Centre (AJRC) conducts research to explore and improve understanding of the economies and economic policy processes in Australia and Japan and both countries' strategic interests in the Asia Pacific economy.

The AJRC Working Paper Series aims to provide a forum for the exchange of topical research and contains the latest research and analysis on the Japanese economy, as well as the political economy, regional integration and trade. The views expressed in AJRC Working Papers are those of the individual authors and do not represent the views of the Australia-Japan Research Centre, the Crawford School, or the institutions to which authors are attached.

The Crawford School of Public Policy is the Australian National University's public policy school, serving and influencing Australia, Asia and the Pacific through advanced policy research, graduate and executive education, and policy impact. 
A Comparison of the Wage Structure between the Public and Private Sectors in Japan

\section{Introduction}

The appropriate level of public sector wages has been debated in every country. Because wages are an important incentive for workers irrespective of their sector, appropriate wage levels and their structure in the public sector is essential for ensuring the quality and efficiency of public services. Several empirical studies have indicated that the wage level of public sector employees (Borjas, 2002; Nickell and Quintini, 2002; Dal Bo et al., 2013) or politicians (Besley, 2004; Gagliarducci and Nannicini, 2013; Mocan and Altindag, 2013) affects the quality of workers and services in the public sector.

Similar to other advanced countries, wages for government officials in Japan are determined by the principle of "equal pay" with those of the private sector, i.e., the overall wage level of the public sector must be balanced with that of the private sector. One reason behind the equal pay principle is the perception of fairness from the viewpoint of nationals and citizens, though equal pay is also important for efficiency in the labor market. In practice, however, the wage structure of public sector has often diverged from that of private sector. As shown in the next section, wages in the public sector are generally less dispersed in major countries. Wages in the public sector are relatively higher at the lower end of the wage/skill distribution and relatively lower at the higher end of the distribution. If the wage level is excessive for some worker types in the public sector, then inefficient rationing is inevitable. However, if the wage level of skilled workers is too low for some worker types in the public sector, the government has difficulty in hiring people with necessary skills, which may negatively influence the quality of public services (Borjas, 2002; Nickell and Quintini, 2002).

As reviewed in the next section, many studies have examined whether the wage level of the public sector is balanced with the private sector (see Ehrenberg and Schwarz, 1986; Bender 1998; Gregory and Borland, 1999, for surveys). However, other studies have noted various difficulties in making accurate comparisons between the two sectors, including 1) the choice of appropriate comparison groups (occupation, size of the organizations, etc.), 2) the control of non-random sorting of individuals between the sectors, and 3) the treatment of compensations other than ordinary salary such as pensions and workplace amenities.

In parallel with the comparison of average wage levels, past studies have identified unique characteristics of public sector wage structure by gender, educational attainments, age groups, and region. However, somewhat surprisingly, formal empirical study employing microdata has 
been almost nonexistent in Japan.

Against this background, this paper, using microdata from the 2007 Employment Status Survey, compares the wage structure between the public and private sectors in Japan. Rather than accurately compare the average wage levels of the two sectors, we focus on the differences in the relative wages by gender, education, age, tenure, and region to present evidence on the differences in the wage structures of the two sectors. The Employment Status Survey is a representative government statistics in which approximately one million people are surveyed. A distinct advantage of the Survey is its coverage of individuals in both public and private sectors. ${ }^{1}$ Employees in both the central government and local governments are included in the Survey. As far as the author is aware, this is the first study that compares wage structures between public and private sectors by employing microdata from this large dataset. $^{2}$

Based on the analysis in this paper, several differences in wage structure are detected. First, wage gaps by gender and educational attainment are smaller in the public sector than in private companies. Second, the public sector's age-wage profile is steeper than that of the private sector. Third, public sector wages are relatively higher at the lower end of the wage distribution and relatively lower at the higher end of the wage distribution. Fourth, the wage differential among regions in the public sector is smaller than the private sector.

The rest of this paper is organized as follows. Section 2 briefly reviews the relevant studies on the comparison of wages between the public and private sectors. Section 3 explains the data used in this paper and the method of analysis. Section 4 reports and interprets the results, and Section 5 concludes with policy implications.

\section{Literature Review}

It is general practice in advanced countries to determine public sector wages by the principle of "equal pay” or "comparability” with the private sector (Linneman and Wachter, 1990; Bender, 2003; Belman and Heywood, 2004b). Numerous studies have examined whether the wage level of public sector workers is balanced with their private sector

\footnotetext{
${ }^{1}$ The Basic Survey on Wage Structure (Ministry of Health, Labor and Welfare), which is the most frequently used source for estimating wage functions in Japan, does not include public sector workers.

2 The National Personnel Authority (2006), by combining two different surveys for government and private companies, reports wage comparisons of central government and private sector workers. However, local government workers, who comprise the majority of public sector workers, are not covered by the survey.
} 
counterparts. Early studies estimated simple wage functions using observable individual characteristics such as education and experience as regressors and decomposed wage differentials between sectors. However, an accurate comparison is extremely difficult due to the treatment of the organizational size, the endogenous sorting of workers between sectors, the lack of data on retirement allowances and pensions (Lewin et al., 2012; Danzer and Dolton, 2012; Gittleman and Pierce, 2012b), differences in wage fluctuations, the risk of unemployment (Cappellari, 2002; Postel-Vinay and Turon, 2007), and other issues (see Gregory and Borland, 1999; Hirsch, 2013, for surveys). Recent empirical studies have attempted to overcome these difficulties by employing detailed datasets and/or new analytical methods.

For example, a simple OLS estimation of wage functions cannot eliminate bias caused by a non-random selection of workers into public and private sectors. To address this issue, analyses with detailed control of occupations (Moulton, 1990; Belman and Heywood, 2004a; Gittleman and Pierce, 2012a) and two-stage estimations using a selection model or a switching regression method (Gyourko and Tracy, 1988; van Ophem, 1993; Dustman and van Soest, 1998; Bender, 2003; Lee, 2004) have been conducted. More recently, Maczulskij (2013) estimated wage gaps between public and private sector employees by applying a within twin pair method for identical twins that was able to control for unobserved ability. Although it is difficult to generalize the results of these studies, controlling for the unobservable productivity of workers by using sample selection methods or longitudinal data tends to find smaller wage gaps relative to simple OLS estimations (Gregory and Borland, 1999).

While the major goal of these studies was to accurately compare the wages of the public and private sectors, several studies have focused on the differences in wage structures between sectors such as the size of female wage discounts, union wage premiums, differences in wages by education, and regional wage disparities. A large number of studies since Smith (1976) have confirmed that the gender wage gap is smaller in public sector (Ehrenberg and Schwarz, 1986; Bender, 1998). Union wage premiums have been found to be greater in the private sector than the public sector (Gregory and Borland, 1999). Many studies have indicated that the wage differential in education is smaller in the public sector (Katz and Krueger, 1991; Poterba and Rueben, 1994; Disney and Gosling, 1998; Belman and 
Heywood, 2004b). ${ }^{3}$ Although regional wage differentials were not the focus of past studies and the results were inconclusive, a study in the U.S. found larger public sector wage premiums in less populated rural regions and lower regional disparities in the public sector wages (Moulton, 1990).

Some studies have recently adopted quantile regression techniques to examine wage gaps at various points in the wage distribution (Mueller, 1998; Lucifora and Meurs, 2006; Gittleman and Pierce, 2012a; Lewin et al, 2012). These studies generally found that wage premiums for public sector workers were greater at the bottom of the wage distribution and lower or even negative at the top of the wage distribution.

To summarize, numerous studies on the public-private comparison of wage levels and structures have been conducted in the U.S. and in European countries and present evidence on the differences between these sectors. However, formal empirical analysis on this subject has been lacking in Japan, partly due to restricted access to official statistics at the disaggregated level. To present new evidence from Japan, this paper uses microdata from the 2007 Employment Status Survey to estimate standard wage functions to compare the wage structure between the public and private sectors. Because the Japanese labor market is known to have unique characteristics such as long-term employment practice and the seniority-based wage structure, analysis of the Japanese wage structure provides valuable information from the viewpoint of international comparison.

\section{Data and Methodology}

The purpose of the Employment Status Survey is to obtain basic facts about employment structure by surveying households in Japan. The survey has been conducted every five years since 1982 by the Statistics Bureau, Ministry of Internal Affairs and Communications. The 2007 survey was conducted on October 1, 2007, and approximately 450,000 households and one million people participated in the survey. Survey items include questions on gender, age, education, employment status, type of employment, industry, occupation, tenure, weekly working hours, and annual income earned. ${ }^{4}$ Most of the survey items are categorical

\footnotetext{
${ }^{3}$ An exception is van Ophem (1993) who found greater educational differences in public sector wages in the Netherlands.

${ }^{4}$ In this paper, we use "annual income" and "wages" interchangeably.
} 
variables with the exception of tenure. For example, annual income is categorized into 15 classes: 1) less than 500 thousand yen, 2) 500 to 999 thousand yen, 3) 1 to 1.49 million yen, 4) 1.5 to 1.99 million yen, 5) 2.0 to 2.49 million yen, ..., 13) 9 to 9.99 million yen, 14) 10 to 14.99 million yen, and 15) 15 million yen or more. Age groups are categorized in 5-year intervals: 1) 15 to 19, 2) 20 to 24 , 3) 25 to $29, \ldots$, 13) 75 to 79, 14) 80 to 84 , and 15) 85 or older. In this paper, age groups over 70 are integrated into a single class. Educational attainment is grouped into six classes: 1) primary school or junior high school, 2) senior high school, 3) vocational school, 4) junior college, 5) college or university, and 6) graduate school. Weekly working hours are categorized into 11 classes: 1) less than 15 hours, 2) 15 to 19 hours, 3) 20 to 21 hours, 4) 22 to 29 hours... 10) 60 to 64 hours, and 11) 65 hours or more.

By using this dataset, we can estimate standard wage functions to explain the log annual income of those who engage in work. The central values of the annual income classes are converted to logarithmic form and used as dependent variable. In the estimations, "less than 500 thousand yen" and "15 million yen or more" are treated as 250 thousand yen and 17.5 million yen, respectively. Explanatory variables include gender (female dummy), age group dummies (age 20 to 24 as the reference), tenure and its square, education dummies (senior high school as the reference), 1-digit occupation dummies, and dummies for weekly working hours. ${ }^{5}$

We eliminate self-employed workers and part-time workers from the sample and estimate the wage functions for regular (standard) employees. In the Employment Status Survey, a "regular employee" is defined as a person who is called a "regular employee" at the workplace. Because the purpose of this paper is to compare wage structures, we estimate wage functions separately for public and private sector employees. Workers in the public sector are identified as those who are employed by the central or local government and their affiliated organizations, which include public schools, hospitals, and research institutes. Unfortunately, we cannot differentiate employees of the central government from those of local governments, but approximately $80 \%$ of public sector workers are employed by local governments (prefectures or cities) in Japan. Thus, a relatively large number of public sector workers in our sample are local government employees.

\footnotetext{
${ }^{5}$ Occupation is classified into 9 categories: 1) administrative and managerial workers, 2) professional and engineering workers, 3) clerical workers, 4) sales workers, 5) service workers, 6) security workers, 7) agriculture, forestry and fishery workers, 8) transport and communication workers, and 9) manufacturing process workers.
} 
In short, the baseline OLS equation to be estimated can be expressed as follows:

$$
\begin{aligned}
& \ln (\text { income })=\beta_{0}+\beta_{1} * \text { female dummy }+\sum \beta_{2} * \text { age dummies }+\beta_{3} * \text { tenure }+\beta_{4} * \text { tenure }{ }^{2} \\
& +\Sigma \beta_{5} * \text { education dummies }+\sum \beta_{6}{ }^{*} \text { occupation dummies }+\Sigma \beta_{7} * \text { hours dummies }+\mu
\end{aligned}
$$

In addition to the above equation, separate estimations are conducted for males and females. When analyzing regional wage differences, we add prefecture dummies as explanatory variables. In this case, Tokyo is used as the reference category and we include 46 prefecture dummies.

As mentioned in the previous section, past studies often employed quantile regression techniques to examine the wage gaps at various points in the wage distribution. To compare our results with the results from other advanced countries, we run similar quantile regressions. In this specification, we pool public and private sector workers and add a dummy for public sector workers.

\section{Results}

\section{4-1. Wage Structure by Individual Characteristics}

The estimation results of the baseline wage function are presented in Table 1. According to the pooled estimations of males and females, the coefficients for the female dummy are negative and highly significant for both public and private sector workers (Table 1, columns (1) and (2)). However, the size of the coefficients is very different between these two sectors. After controlling for age, tenure, weekly working hours, and occupation, the size of the female wage discount in the private sector is approximately $50 \%$, but only $14 \%$ in the public sector. In other words, the male-female wage gap is far smaller in the public sector than the private sector. While this result is qualitatively similar to the results in other advanced countries, the difference in the size of the gender wage gap between the two sectors is quantitatively very large in Japan. ${ }^{6}$ The result suggests that females have an incentive to

\footnotetext{
${ }^{6}$ According to a survey article by Gregory and Borland (1999), difference in the size of the gender wage gap between public and private sectors is less than $10 \%$ in the U.S. and around $10 \%$ in the European countries.
} 
self-select into public sector jobs due to the delay in gender neutral treatment in Japanese private companies.

To explore the female wage discount further, we restrict the sample to female workers to analyze the effects of marriage and childbearing on wages. Specifically, we estimate the wage functions where the existence of spouses and preschool children (children less than 6 years of age) are additional explanatory variables. The estimation results are presented in Table 2. After controlling for various observable individual characteristics, married females in the private sector endure a $10 \%$ wage discount relative to unmarried females. In contrast, in the public sector, the coefficient for marriage is statistically insignificant. The negative effect of marriage on female wages is smaller in the public sector than the private sector. When comparing the married ratios in the two sectors, the ratio is higher in the public sector throughout the age classes, suggesting that the potential selection bias arising from low-earning females' exit from the labor force after their marriage is not a reason behind the above result. If anything, the opposite is true. However, the negative relationship between the existence of preschool children and wages are similar in magnitude for the public and private sectors, although the absolute size of the coefficients is small (approximately 2\%).

When looking at the coefficients for education dummies, clear differences between the two sectors can be observed. In the private sector, wage premiums relative to high school are more than $20 \%$ for undergraduate and more than $40 \%$ for postgraduate education, respectively. However, the premium for advanced education is far smaller in the public sector: approximately $10 \%$ for undergraduate and $25 \%$ for postgraduate education (see Table 1 , columns (1) and (2)). When splitting the sample by gender, wage premiums for advanced education are very substantial for female workers in the private sector (Table 1, columns (5) and (6)). In short, wage differentials among educational classes are small in the public sector: workers with lower education enjoy relatively higher wages and workers with higher education suffer from relatively lower wages. As a consequence, the private rate of return for higher education halves when working in the public sector. This result suggests a possibility that the public sector may have difficulty in hiring excellent graduates from undergraduate and postgraduate schools.

The age-wage profile drawing from the estimated coefficients for age dummies is steeper in the public sector than the private sector (Figure 1). In the estimations, the coefficient for age classes is the "pure age effect" controlling for the tenure of workers. That is, in the 
public sector, relatively older workers enjoy relatively higher wages. However, a "pure tenure effect" on wages controlling for age is not fundamentally different between the two sectors.

As we noted in Section 2, studies conducted quantile regression to see public-private wage gaps at various points in the wage distribution. To see the difference with other countries, we run similar quantile regressions where we pool the sample of public and private sector workers and add a public sector dummy. The explanatory variables are the same with the baseline OLS specification. We choose five points in the wage distribution: $q=0.1, q=0.25$, $\mathrm{q}=0.5, \mathrm{q}=0.75$, and $\mathrm{q}=0.9$. Our interest here is the difference in the estimated coefficients for the public sector dummy among the quantiles. Similar to past studies in other countries, the coefficients are larger at the lower side of wage distribution and smaller at the higher side (Table 3). ${ }^{7}$ In particular, the coefficients at $\mathrm{q}=0.75$ and $\mathrm{q}=0.9$ are negative and significant in the estimation for male workers (Table 3, Column (2)).

\section{4-2. Regional Wage Differential}

Regional wage differentials for private sector workers have been frequently analyzed for the purpose of finding evidence on the agglomeration economies. These studies have clearly shown that the wages are higher in densely populated regions when accounting for individual characteristics and the sorting of individuals among regions (Combes et al., 2011 and Moretti, 2011, for surveys). The theoretical background of the observed regional wage differentials is essentially the different productivity arising from the agglomeration economies. However, studies that compare the regional wage structure between public and private sectors have been scarce.

In this paper, we use regional (prefecture) dummies as additional explanatory variables in estimating wage functions. In the estimations, Tokyo is used as the reference prefecture. Figure 2 indicates the regional wage differentials drawing from the estimated coefficients for the prefecture dummies. It is obvious that the regional wage differentials are smaller in the

\footnotetext{
7 The estimated coefficients for the public sector dummy can be interpreted as the public sector wage premium or discount. However, as mentioned in Section 2, many reservations should be made when interpreting the simple regression results. It should be stressed that the focus of this paper is the difference in "wage structure" between public and private sectors.
} 
public sector than the private sector after controlling for the observable worker characteristics. The standard deviations of the estimated coefficients are 0.050 and 0.110 for the public and private sectors, respectively. When replacing the prefecture dummies to the population density of the prefectures as explanatory variable to measure the elasticity of wages with respect to the population density, the estimated elasticity for the public sector is 0.038 , which is less than half of the elasticity for the private sector $(0.081)$. In less populated regions where private sector wages are lower tend to have relatively higher wages in the public sector, suggesting that wages in the public sector may deviate from the "spatial equilibrium.”

Past studies on public-private wage differentials have employed regional dummies, but they typically treated them as control variables and did not pay particular attention to their coefficients. An exception is Moulton (1990), who analyzed the federal-private wage differential in the U.S. by dividing the sample into three metropolitan areas according to population size. ${ }^{8}$ The results showed that the public-private wage differential was smaller in high-wage large metropolitan areas than in smaller metropolitan areas that tend to have lower private-sector wages. The differences in public-private wages by the population size of the regions are 5\% or less. The result of this paper is qualitatively similar to Moulton (1990), but the small wage differential among regions in the public sector workers is remarkable in Japan.

\section{Conclusions}

This paper compares the wage structures between the public and private sectors in Japan by estimating standard wage functions using microdata from the 2007 Employment Status Survey. Past studies have shown that it is very difficult to accurately compare the overall wage levels between the private and public sectors. Rather than comparing the average wage levels between the sectors, we focus on the differences in the wage structures.

The results of the analysis can be summarized as follows. First, wage gaps by gender and educational attainment are smaller in the public sector compared with those of private companies. These results are similar to past studies in other countries, but it should be noted

\footnotetext{
${ }^{8}$ Populations of 250 thousand and 2.5 million are used as threshold values.
} 
that the quantitative difference in the gender wage gaps between the two sectors is very large in Japan. Second, the public sector's age-wage profile is steeper than that of the private sector. Third, public sector wages are relatively higher at the lower end of the wage distribution and relatively lower at the higher end of the wage distribution. Finally, regional differences in wage levels are smaller in public sector workers. As a result, the wage level of public workers is relatively higher in less populated rural regions.

These findings indicate that the wage structure of the public sector is different from that of the private sector in Japan, suggesting public sector wages may deviate from the equilibrium in the labor market. For example, relatively small wage premiums for higher education may have serious effects on hiring excellent graduates in the public sector. The smaller regional wage differential may cause skilled individuals in rural regions to self-select into public sector jobs. At the same time, public sectors in metropolitan regions such as Tokyo may have difficulty in hiring high quality workers. Smaller gender wage gaps and marriage wage penalties in the public sector suggest that females may not be well utilized in private companies in Japan. Finally, to ensure the quality of public services, it is inappropriate to simply focus on the average public-private wage gap when discussing public sector wages. Analyzing overall wage structures by gender, skill, or region will be necessary. 


\section{References}

Belman, Dale and John S. Heywood (2004a), "Public Wage Differentials and the Treatment of Occupational Differences,” Journal of Policy Analysis and Management, Vol. 23, No. 1, pp. 135-152.

Belman, Dale and John S. Heywood (2004b), "Public-Sector Wage Comparability: The Role of Earnings Dispersion,” Public Finance Review, Vol. 32, No. 6, pp. 567-587.

Bender, Keith A. (1998), "The Central Government-Private Sector Wage Differential," Journal of Economic Surveys, Vol. 12, No. 2, pp. 177-220.

Bender, Keith A. (2003), “Examining Equality between Public- and Private-Sector Wage Distributions,” Economic Inquiry, Vol. 41, No. 1, pp. 62-79.

Besley, Timothy (2004), "Paying Politicians: Theory and Evidence," Journal of the European Economic Association, Vol. 2, Nos. 2-3, pp. 193-215.

Borjas, George J. (2002), “The Wage Structure and the Sorting of Workers into the Public Sector,” NBER Working Paper, No. 9313.

Cappellari, Lorenzo (2002), “Earnings Dynamics and Uncertainty in Italy: How Do They Differ between the Private and Public Sectors,” Labour Economics, Vol. 9, No. 4, pp. 477-496.

Combes, Pierre-Philippe, Gilles Duranton, and Laurent Gobillon (2011), “The Identification of Agglomeration Economies,” Journal of Economic Geography, Vol. 11, No. 2, pp. 253266.

Dal Bo, Ernesto, Frederico Finan, and Martin A. Rossi (2013), "Strengthening State Capabilities: The Role of Financial Incentives in the Call to Public Service,” Quarterly Journal of Economics, Vol. 128, No. 3, pp. 1169-1218.

Danzer, Alexander M. and Peter J. Dolton (2012), “Total Reward and Pensions in the UK in the Public and Private Sectors,” Labour Economics, Vol. 19, No. 4, pp. 584-594.

Disney, Richard and Amanda Gosling (1998), “Does It Pay to Work in the Public Sector?” Fiscal Studies, Vol. 19, No. 4, pp. 347-374.

Dustmann, Christian and Arthur van Soest (1998), "Public and Private Sector Wages of Male Workers in Germany,” European Economic Review, Vol. 42, No. 8, pp. 1417-1441.

Ehrenberg, Ronald G. and Joshua L. Schwarz (1986), “Public-Sector Labor Markets,” in O. Ashenfelter and R. Layard eds. Handbook of Labor Economics, Vol. 2, Amsterdam, The 
Netherlands: Elsevier, pp.1219-1260.

Gagliarducci, Stefano and Tommaso Nannicini (2013), “Do Better Paid Politicians Perform

Better? Disentangling Incentives from Selection,” Journal of the European Economic Association, Vol. 11, No. 2, pp. 369-398.

Gittleman, Maury, and Brooks Pierce (2012a), "Compensation for State and Local

Government Workers,” Journal of Economic Perspectives, Vol. 26, No. 1, pp. 217-242.

Gittleman, Maury and Brooks Pierce (2012b), “Inter-Industry Compensation Differentials,” BLS Working Paper, No. 453.

Gregory, Robert G. and Jeff Borland (1999), “Recent Developments in Public Sector Labor Markets,” in O. Ashenfelter and D. Card eds. Handbook of Labor Economics, Vol. 3, Amsterdam, The Netherlands: Elsevier, pp. 3573-3630.

Gyourko, Joseph and Joseph Tracy (1988), “An Analysis of Public- and Private-Sector Wage Allowing for Endogenous Choices of Both Government and Union Status,” Journal of Labor Economics, Vol. 6, No. 2, pp. 229-253.

Hirsch, Barry T. (2013), “An Anatomy of Public Sector Unions,” IZA Discussion Paper, No. 7313.

Katz, Lawrence F. and Alan B. Krueger (1991), "Changes in the Structure of Wages in the Public and Private Sectors,” NBER Working Paper, No. 3667.

Lee, Sang-Hyop (2004), “A Reexamination of Public-Sector Wage Differentials in the United States: Evidence from the NLSY with Geocode,” Industrial Relations, Vol. 43, No. 2, pp. 448-472.

Lewin, David, Jeffrey H. Keefe, and Thomas A. Kochan (2012), “The New Great Debate about Unionism and Collective Bargaining in U.S. State and Local Governments,” Industrial and Labor Relations Review, Vol. 65, No. 4, pp. 749-778.

Linneman, Peter D. and Michael L. Wachter (1990), "The Economics of Federal Compensation,” Industrial Relations, Vol. 29, No. 1, pp. 58-76.

Lucifora, Claudio and Dominique Meurs (2006), "The Public Sector Pay Gap in France, Great Britain and Italy,” Review of Income and Wealth, Vol. 52, No. 1, pp. 43-59.

Maczulskij, Terhi (2013), “Employment Sector and Pay Gaps: Genetic and Environmental Influences,” Labour Economics, Vol. 23, August, pp. 89-96.

Mocan, Naci and Duha T. Altindag (2013), "Salaries and Work Effort: An Analysis of the European Union Parliamentarians,” Economic Journal, Vol. 123, December, pp. 
$1130-1167$.

Moretti, Enrico (2011), “Local Labor Markets,” in Orley Ashenfelter and David Card eds., Handbook of Labor Economics, Vol. 4b, Amsterdam, The Netherlands: Elsevier, pp. 1237-1313.

Moulton, Brent R. (1990), “A Reexamination of the Federal-Private Wage Differential in the United States,” Journal of Labor Economics, Vol. 8, No. 2, pp. 270-293.

Mueller, Richard E. (1998), "Public-Private Sector Wage Differentials in Canada: Evidence from Quantile Regressions,” Economics Letters, Vol. 60, No. 2, pp. 229-235.

Nickell, Stephen and Glenda Quintini (2002), “The Consequences of the Decline in Public Sector Pay in Britain: A Little Bit of Evidence,” Economic Journal, Vol. 112, February, F107-F112.

Postel-Vinay, Fabien and Helene Turon (2007), “The Public Pay Gap in Britain: Small Differences that (don't) Matter,” Economic Journal, Vol. 117, October, pp. 1460-1503.

Poterba, James M. and Kim S. Rueben (1994), “The Distribution of Public Sector Wage Premia: New Evidence Using Quantile Regression Methods,” NBER Working Paper, No. 4734.

Smith, Sharon P. (1976), "Government Wage Differentials by Sex,” Journal of Human Resources, Vol. 11, No. 2, pp. 185-199.

The National Personnel Authority (2006), “A Report on the Method to Compare Wages between Public and Private Sector.” (in Japanese.)

van Ophem, Hans (1993), “A Modified Switching Regression Model for Earnings Differentials between the Public and Private Sectors in the Netherlands," Review of Economics and Statistics, Vol. 75, No. 2, pp. 215-224. 
Table 1: Estimation results of the baseline wage function

\begin{tabular}{|c|c|c|c|c|c|c|c|c|c|c|c|c|}
\hline \multirow{3}{*}{ Female } & \multicolumn{4}{|c|}{ Male and female } & \multicolumn{4}{|c|}{ Male } & \multicolumn{4}{|c|}{ Female } \\
\hline & \multicolumn{2}{|c|}{ (1) Public } & \multicolumn{2}{|c|}{ (2) Private } & \multicolumn{2}{|c|}{ (3) Public } & \multicolumn{2}{|c|}{ (4) Private } & \multicolumn{2}{|c|}{ (5) Public } & \multicolumn{2}{|c|}{ (6) Private } \\
\hline & -0.1390 & $* * *$ & -0.4983 & $* * *$ & & & & & & & & \\
\hline & $(0.0035)$ & & $(0.0028)$ & & & & & & & & & \\
\hline \multirow[t]{2}{*}{$\begin{array}{l}\text { Junior high } \\
\text { school }\end{array}$} & -0.1384 & $* * *$ & -0.1417 & $* * *$ & -0.1204 & $* * *$ & -0.1491 & $* * *$ & -0.1822 & $* * *$ & -0.1239 & $* * *$ \\
\hline & $(0.0146)$ & & $(0.0039)$ & & $(0.0163)$ & & $(0.0041)$ & & $(0.0306)$ & & $(0.0095)$ & \\
\hline \multirow[t]{2}{*}{$\begin{array}{l}\text { Vocational } \\
\text { school }\end{array}$} & 0.0282 & $* * *$ & -0.0005 & & 0.0014 & & -0.0107 & $* * *$ & 0.0584 & $* * *$ & 0.0223 & $* * *$ \\
\hline & $(0.0060)$ & & $(0.0037)$ & & $(0.0086)$ & & $(0.0041)$ & & $(0.0101)$ & & $(0.0081)$ & \\
\hline \multirow[t]{2}{*}{ Junior college } & 0.0198 & $* * *$ & 0.1050 & $* * *$ & 0.0253 & $* * *$ & 0.1069 & $* * *$ & 0.0335 & $* * *$ & 0.0987 & $* * *$ \\
\hline & $(0.0056)$ & & $(0.0045)$ & & $(0.0092)$ & & $(0.0064)$ & & $(0.0090)$ & & $(0.0068)$ & \\
\hline \multirow[t]{2}{*}{ University } & 0.0982 & $* * *$ & 0.2236 & $* * *$ & 0.0869 & $* * *$ & 0.1970 & $* * *$ & 0.1269 & $* * *$ & 0.2749 & $* * *$ \\
\hline & $(0.0040)$ & & $(0.0028)$ & & $(0.0044)$ & & $(0.0030)$ & & $(0.0089)$ & & $(0.0078)$ & \\
\hline \multirow[t]{2}{*}{$\begin{array}{l}\text { Graduate } \\
\text { school }\end{array}$} & 0.2579 & $* * *$ & 0.4437 & $* * *$ & 0.2453 & $* * *$ & 0.4386 & $* * *$ & 0.2804 & $* * *$ & 0.4986 & $* * *$ \\
\hline & $(0.0079)$ & & $(0.0088)$ & & $(0.0085)$ & & $(0.0087)$ & & $(0.0194)$ & & $(0.0345)$ & \\
\hline \multirow[t]{2}{*}{$15-19$} & -0.1448 & $* * *$ & -0.0519 & $* * *$ & -0.0933 & ** & -0.0738 & $* * *$ & -0.2152 & $* *$ & 0.0096 & \\
\hline & $(0.0392)$ & & $(0.0116)$ & & $(0.0423)$ & & $(0.0138)$ & & $(0.0985)$ & & $(0.0211)$ & \\
\hline \multirow[t]{2}{*}{$25-29$} & 0.1072 & $* * *$ & 0.0760 & $* * *$ & 0.1420 & $* * *$ & 0.1179 & $* * *$ & 0.0857 & $* * *$ & 0.0500 & $* * *$ \\
\hline & $(0.0097)$ & & $(0.0053)$ & & $(0.0137)$ & & $(0.0063)$ & & $(0.0140)$ & & $(0.0100)$ & \\
\hline \multirow[t]{2}{*}{ 30-34 } & 0.2329 & $* * *$ & 0.1494 & $* * *$ & 0.3108 & $* * *$ & 0.2311 & $* * *$ & 0.1564 & $* * *$ & 0.0647 & $* * *$ \\
\hline & $(0.0099)$ & & $(0.0052)$ & & $(0.0137)$ & & $(0.0061)$ & & $(0.0149)$ & & $(0.0104)$ & \\
\hline \multirow[t]{2}{*}{ 35-39 } & 0.3429 & $* * *$ & 0.2086 & $* * *$ & 0.4499 & $* * *$ & 0.3118 & $* * *$ & 0.2157 & $* * *$ & 0.0644 & $* * *$ \\
\hline & $(0.0108)$ & & $(0.0054)$ & & $(0.0146)$ & & $(0.0062)$ & & $(0.0167)$ & & $(0.0108)$ & \\
\hline \multirow[t]{2}{*}{$40-44$} & 0.4302 & $* * *$ & 0.2466 & $* * *$ & 0.5579 & $* * *$ & 0.3696 & $* * *$ & 0.2678 & $* * *$ & 0.0394 & $* * *$ \\
\hline & $(0.0114)$ & & $(0.0055)$ & & $(0.0153)$ & & $(0.0064)$ & & $(0.0179)$ & & $(0.0111)$ & \\
\hline \multirow[t]{2}{*}{$45-49$} & 0.4607 & $* * *$ & 0.2362 & $* * *$ & 0.6019 & $* * *$ & 0.3703 & $* * *$ & 0.2729 & $* * *$ & -0.0032 & \\
\hline & $(0.0118)$ & & $(0.0057)$ & & $(0.0158)$ & & $(0.0066)$ & & $(0.0188)$ & & $(0.0113)$ & \\
\hline $50-54$ & 0.4999 & $* * *$ & 0.2154 & $* * *$ & 0.6568 & $* * *$ & 0.3528 & $* * *$ & 0.2786 & $* * *$ & -0.0290 & $* *$ \\
\hline & $(0.0121)$ & & $(0.0057)$ & & $(0.0161)$ & & $(0.0066)$ & & $(0.0196)$ & & $(0.0114)$ & \\
\hline $55-59$ & 0.5216 & $* * *$ & 0.1848 & $* * *$ & 0.6887 & $* * *$ & 0.3247 & $* * *$ & 0.2775 & $* * *$ & -0.0650 & $* * *$ \\
\hline & $(0.0126)$ & & $(0.0057)$ & & $(0.0166)$ & & $(0.0065)$ & & $(0.0209)$ & & $(0.0116)$ & \\
\hline $60-64$ & 0.4318 & $* * *$ & -0.0091 & & 0.5642 & $* * *$ & 0.1150 & $* * *$ & 0.2272 & $* * *$ & -0.1922 & $* * *$ \\
\hline & $(0.0148)$ & & $(0.0067)$ & & $(0.0183)$ & & $(0.0076)$ & & $(0.0289)$ & & $(0.0144)$ & \\
\hline $65-69$ & 0.0703 & $* *$ & -0.2174 & $* * *$ & 0.2032 & $* * *$ & -0.1091 & $* * *$ & -0.4201 & $* * *$ & -0.3261 & $* * *$ \\
\hline & $(0.0315)$ & & $(0.0087)$ & & $(0.0336)$ & & $(0.0098)$ & & $(0.0947)$ & & $(0.0184)$ & \\
\hline 70- & -0.1005 & $* * *$ & -0.3855 & $* * *$ & 0.0032 & & -0.3226 & $* * *$ & -0.3127 & $* * *$ & -0.3444 & $* * *$ \\
\hline & $(0.0386)$ & & $(0.0099)$ & & $(0.0419)$ & & $(0.0113)$ & & $(0.1001)$ & & $(0.0209)$ & \\
\hline Tenure & 0.0221 & $* * *$ & 0.0263 & $* * *$ & 0.0171 & $* * *$ & 0.0254 & $* * *$ & 0.0305 & $* * *$ & 0.0314 & $* * *$ \\
\hline & $(0.0008)$ & & $(0.0003)$ & & $(0.0009)$ & & $(0.0003)$ & & $(0.0014)$ & & $(0.0007)$ & \\
\hline Tenure $^{2}$ & -0.0002 & $* * *$ & -0.0003 & $* * *$ & -0.0001 & $* * *$ & -0.0003 & $* * *$ & -0.0003 & $* * *$ & -0.0005 & $* * *$ \\
\hline & $(0.0000)$ & & $(0.0000)$ & & $(0.0000)$ & & $(0.0000)$ & & $(0.0000)$ & & $(0.0000)$ & \\
\hline Occupation & yes & & yes & & yes & & yes & & yes & & yes & \\
\hline $\begin{array}{l}\text { Working } \\
\text { hours }\end{array}$ & yes & & yes & & yes & & yes & & yes & & yes & \\
\hline Adj. $R^{2}$ & 0.5928 & & 0.4186 & & 0.5745 & & 0.3615 & & 0.5597 & & 0.2054 & \\
\hline Nobs & 36,180 & & 204,561 & & 23,795 & & 155,217 & & 12,385 & & 49,344 & \\
\hline
\end{tabular}

(Notes) OLS estimations with standard errors in parentheses. ***, **, and * indicate significance at the $1 \%, 5 \%$, and $10 \%$ levels, respectively. Senior high school and age $20-24$ are the reference categories. 
Table 2: Wage penalty of marriage and preschool children on female workers

\begin{tabular}{|c|c|c|c|c|}
\hline & \multicolumn{2}{|c|}{ (1) Public } & \multicolumn{2}{|c|}{ (2) Private } \\
\hline \multirow[t]{2}{*}{ Married } & 0.0046 & & -0.1044 & $* * *$ \\
\hline & $(0.0066)$ & & $(0.0057)$ & \\
\hline \multirow[t]{2}{*}{ Pres chool children } & -0.0203 & ** & -0.0150 & * \\
\hline & $(0.0082)$ & & $(0.0083)$ & \\
\hline
\end{tabular}

(Notes) OLS estimations with standard errors in parentheses. ***, **, and * indicate significance at the $1 \%, 5 \%$, and $10 \%$ levels, respectively. Marriage dummy is assigned those who currently have spouses (divorced and widowed are not included). Preschool children are children under 6 years of age.

Table 3: Public sector wage premium/discount at different points of wage distribution (quantile regression results)

\begin{tabular}{|c|c|c|c|c|c|c|c|c|c|}
\hline & \multicolumn{3}{|c|}{ (1) Male and female } & & \multicolumn{2}{|l|}{ (2) Male } & & \multicolumn{2}{|l|}{ (3) Female } \\
\hline \multirow[t]{2}{*}{$q=0.10$} & & 0.2946 & $* * *$ & & 0.2255 & $* * *$ & & 0.4080 & $* * *$ \\
\hline & $\vec{v}$ & $(0.0039)$ & & $T$ & $(0.0053)$ & & $T$ & $(0.0116)$ & \\
\hline \multirow[t]{2}{*}{$q=0.25$} & & 0.2347 & $* * *$ & & 0.1515 & $* * *$ & & 0.3909 & $* * *$ \\
\hline & $T$ & $(0.0031)$ & & 7 & $(0.0039)$ & & $F$ & $(0.0069)$ & \\
\hline \multirow[t]{2}{*}{$q=0.50$} & & 0.1516 & $* * *$ & & 0.0550 & $* * *$ & & 0.3394 & $* * *$ \\
\hline & & $(0.0033)$ & & $T$ & $(0.0041)$ & & $r$ & $(0.0051)$ & \\
\hline \multirow[t]{2}{*}{$q=0.75$} & & 0.0763 & $* * *$ & & -0.0440 & $* * *$ & & 0.2286 & $* * *$ \\
\hline & & $(0030)$ & & $F$ & $(0.0046)$ & & $F$ & $(0.0059)$ & \\
\hline \multirow[t]{2}{*}{$q=0.90$} & & 0.0067 & $*$ & & -0.1177 & $* * *$ & & 0.1225 & $* * *$ \\
\hline & & $(0.0041)$ & & & $(0.0044)$ & & & $(0.0056)$ & \\
\hline Nobs & & 240,741 & & & 179,012 & & & 61,729 & \\
\hline
\end{tabular}

(Notes) Quantile regressions with standard errors in parentheses. ***,**, and * indicate significance at the $1 \%, 5 \%$, and $10 \%$ levels, respectively. Explanatory variables include gender (only for column (1)), education, age classes, tenure and its square, occupation, and weekly working hours. 
Figure 1: Age-wage profiles

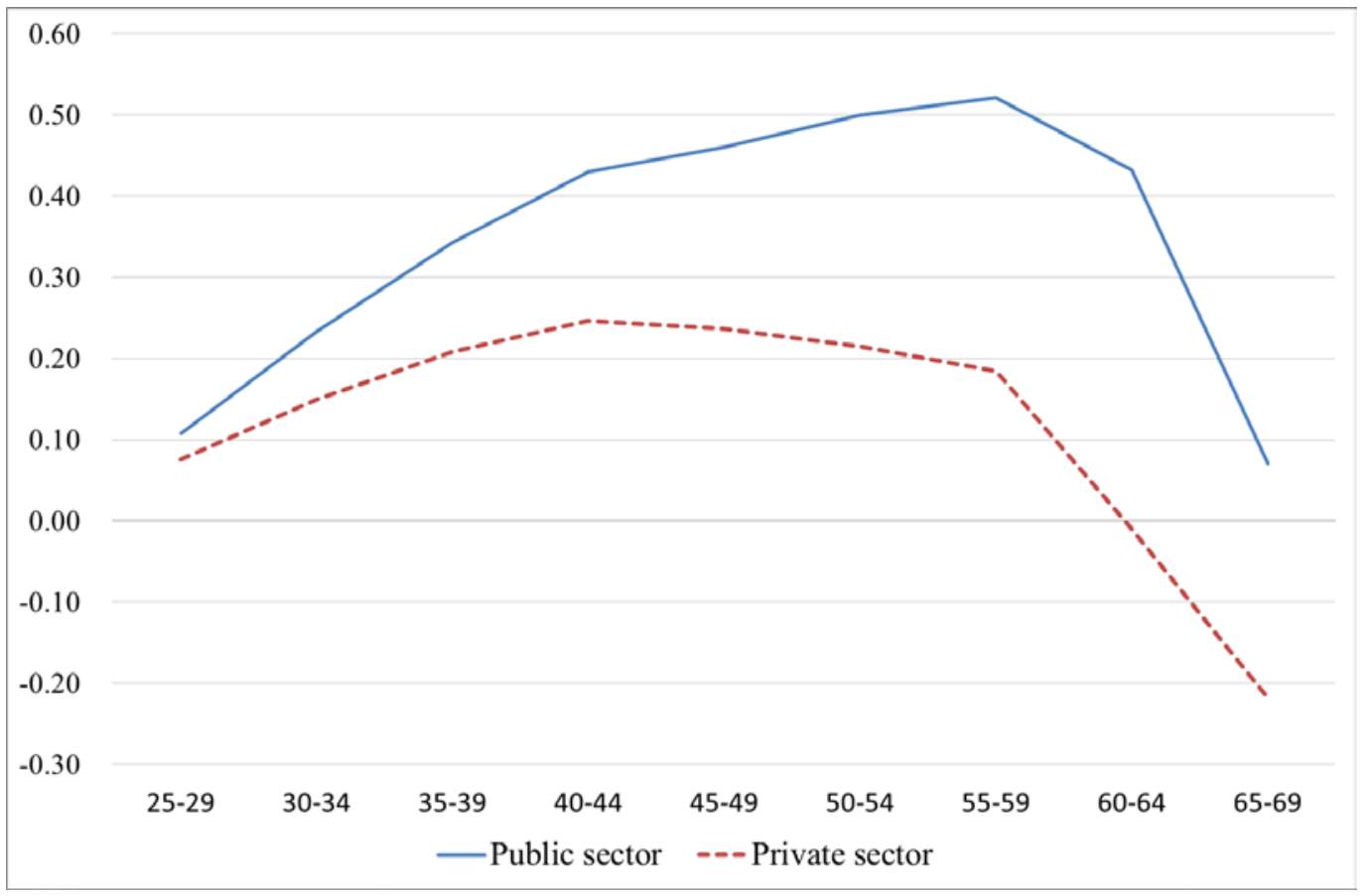

(Notes) Estimated from microdata of the 2007 Employment Status Survey. The vertical axis indicates the coefficients for the age classes (log annual income). Explanatory variables include gender (female dummy), education, age classes (20-24 is the reference category), tenure and its square, occupation, and weekly working hours. 
Figure 2: Wage differentials by region

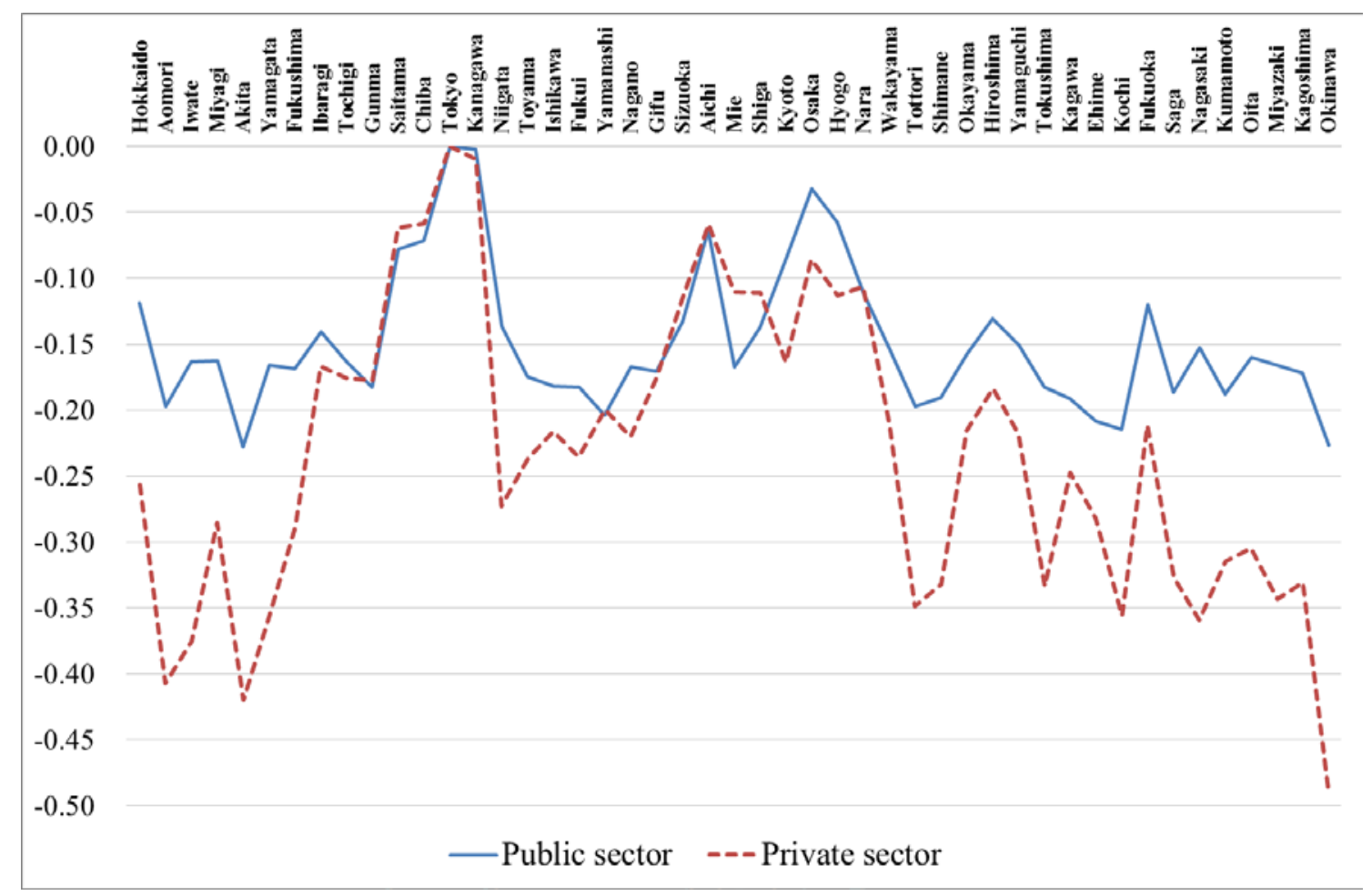

(Notes) Estimated from microdata of the 2007 Employment Status Survey. The vertical axis indicates the coefficients for the age classes (log annual income). Explanatory variables include gender (female dummy), education, age classes (20-24 is the reference category), tenure and its square, occupation, weekly working hours, and prefecture dummies (Tokyo is the reference region). 